\title{
HEREDITARY FACTORS IN RHEUMATOID ARTHRITIS AND ANKYLOSING SPONDYLITIS
}

BY

\author{
J. J. De BlÉCOURT, THE late A. POLMAN, AND T. De BlÉCOURT-MEINDERSMA \\ From the Department of Rheumatic Diseases, The Clinic of Internal Diseases, \\ and the Anthropogenetic Institute, University of Groningen, The Netherlands
}

\section{With a Statistical Appendix By}

\section{T. J. D. ERLEE AND E. F. DRION}

There have been few scientifically acceptable publications on the significance of hereditary factors in various rheumatic diseases. Only in the past few years has attention been given to reliable differential diagnosis between the various forms of rheumatism. Of the older authors we may mention Fox and van Breemen (1934), who spoke of the "red thread of secondary cases" of various rheumatic affections which might be observed in the family of a rheumatic patient. Hangarter (1938), who presented a survey of the literature on the subject, believed that various rheumatic conditions, such as rheumatic fever, rheumatoid arthritis, ankylosing spondylitis, and osteo-arthritis, might occur side by side in certain families. These authors attached considerable importance to the so-called "rheumatic diathesis". Holsti and Huuskonen (1938) reported a mass examination (by inquiry) among 195,000 Finnish subjects; 0.9 per cent. were found to be suffering from some rheumatic condition, and various forms of rheumatism occurred in the same family.

Of the current investigators in this field, Stecher and his co-workers should be mentioned first. Stecher (1957), who reported exhaustive personal observations with a comprehensive survey of the literature, maintained that any study of heredity should be based on patients in whom the diagnosis had been made with meticulous accuracy, and that the data considered should be only those pertaining to the diseases chosen as a starting point. He believed that a specific hereditary mechanism was involved in every form of articular rheumatism, not excluding the various forms of arthrosis and spondylosis deformans. It should be borne in mind that a possible "hereditary factor" does not per se determine the manifestation of a rheumatic condition, and that other endogenous and exogenous factors also govern the actual appearance of the rheumatic affection.

The familial occurrence and possible involvement of a hereditary factor in ankylosing spondylitis (Bechterew's disease) had previously attracted our attention, and it was decided to institute an investigation of possible hereditary factors and to include rheumatoid arthritis in our survey.

\section{Method and Material}

Probands.-From the patients of the "Groningen Rheumatic Centre" we obtained a random series of 100 cases of ankylosing spondylitis and 100 cases of rheumatoid arthritis. A control group of 100 subjects normal at that time was also included. These $\mathbf{3 0 0}$ probands were aged between 25 and 45 , and an attempt was made to avoid predominance of either sex.

Diagnosis.-The diagnosis of rheumatoid arthritis had to be "definitive" (Ropes, Bennett, Cobb, Jacox, and Jessar, 1957).

Ankylosing spondylitis was regarded as "definitive" in patients showing typical $x$-ray changes in the sacroiliac joints and sometimes the vertebral column, spinal ankylosis, and a typical history and symptoms.

The probands of the control group were also examined (at the out-patient clinic), and only those were included who were quite free from arthritis and spondylitis.

In determining the results of the subsequent examination of the relatives of these 300 probands, the same criteria were used as regards a possible diagnosis of "rheumatoid arthritis" or "ankylosing spondylitis".

Relatives.-The completest possible pedigree was obtained for each of the $\mathbf{3 0 0}$ probands. All accessible grandparents, parents, siblings, children, and collateral members of the family were examined. 
Persons under 15 years of age were omitted from the investigation for two reasons:

(i) Rheumatoid arthritis and ankylosing spondylitis are exceedingly rare before the 15 th year.

(ii) Comparison was thereby facilitated between our results and those of other mass investigations in the Netherlands, which were also limited to subjects aged 15 years and over (de Blécourt, 1951a, b, 1954; de Graaff, 1961).

All the relatives were examined at home by the same specially trained physician. If the diagnosis was doubtful the subject was referred to a rheumatic diseases out-patient clinic for further investigation.

\section{Results}

Completion Rate.-A rate of 100 per cent. is obviously impossible to obtain in an investigation covering some thousands of relatives. The cooperation offered by all agencies and persons concerned proved to be such, however, that a rate of nearly 87 per cent. was achieved. The details are shown in Table I, which should be read as follows:

Rheumatoid Arthritis.-The average age of the 100 probands of this group ( 38 males and 62 females) was 38.8 years: the total number of their relatives was 3,256 , but only 2,842 of these were over 15 years of age. Of this number $2,486(87.5$ per cent.) were contacted and included in the survey.

Ankylosing Spondylitis.-The average age of the 100 probands of this group ( 76 males and 24 females) was $36 \cdot 7$ years: their relatives numbered 3,170 , of whom 2,862 were over 15 years of age; 2,478 ( 86.6 per cent.) were included.

Healthy Controls.-The average age of the 100 probands of this group (48 males and 52 females) was 38.6 years: their relatives numbered 3,141 , of whom 2,825 were over $15 ; 2,441$ (86.4 per cent.) were included.
Total.-The three groups together included 8,529 relatives aged 15 years and over, of whom 7,405 $(86.8$ per cent.) were included in the investigation.

Secondary Cases.-The occurrence of secondary cases in the three groups of relatives is shown in Table II (opposite):

Rheumatoid Arthritis Group.-Among 2,486 relatives, there were 58 cases $(2.35$ per cent.). The occurrence of such secondary cases was higher. amongst female relatives $(3.48$ per cent.) than $\overrightarrow{\vec{\omega}}$ amongst male relatives $(1 \cdot 25$ per cent.).

These percentages may be contrasted with the occurrence of only twenty secondary cases of rheumatoid arthritis amongst the 2,441 relatives of the control group $(0.82$ per cent. $)$ : amongst male ${ }_{i}^{\omega}$ relatives 0.4 per cent. and amongst female relatives, $\vec{\sigma}$ $1 \cdot 2$ per cent.

Ankylosing Spondylitis Group.-Among 2,478 $\overrightarrow{\mathrm{c}}$ relatives, 45 secondary cases of ankylosing spondy- $\frac{\mathbb{D}}{\mathrm{O}}$ litis were found (1.8 per cent.). But here, in con- $\mathbb{\mathbb { D }}$ trast to the experience in the rheumatoid arthritis 3 group, the occurrence of secondary cases was higher $\mathbb{Q}$ amongst the male relatives $(2.45$ per cent.) thag $\vec{\theta}$ amongst the female relatives ( $1 \cdot 20$ per cent.).

Control Group.-There were only two "secondarys cases of ankylosing spondylitis amongst the 2,441 relatives of the controls $(0.08$ per cent.): amongst males $0 \cdot 17$ per cent. but amongst females nil.

Affected Families. - Table III (opposite) shows for $\overline{\bar{O}}$ each group the porportion of families with $0,1,2, \exists$ etc., secondary cases of the same disease.

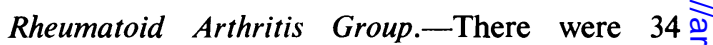
families showing 58 secondary cases, i.e. a familial occurrence of 34 per cent. Of these 34 familial 3 occurrences, fifteen were via the male and thirteen

TABLE I

PERSONS INCLUDED IN THE SURVEY

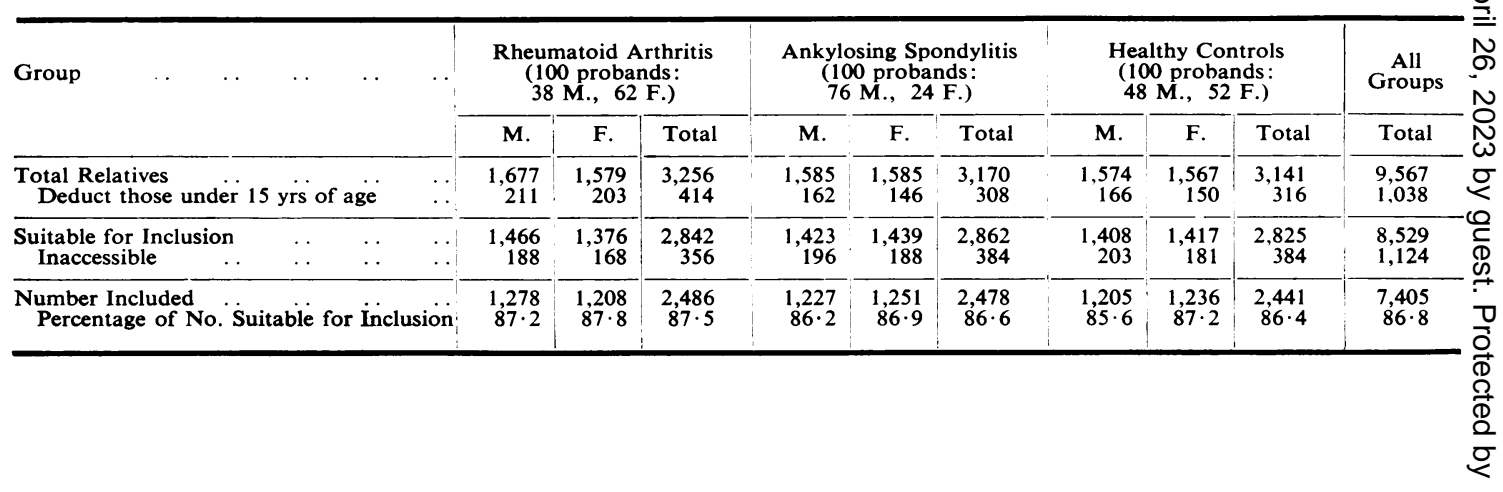


TABLE II

PREVALENCE OF SECONDARY CASES AMONGST RELATIVES

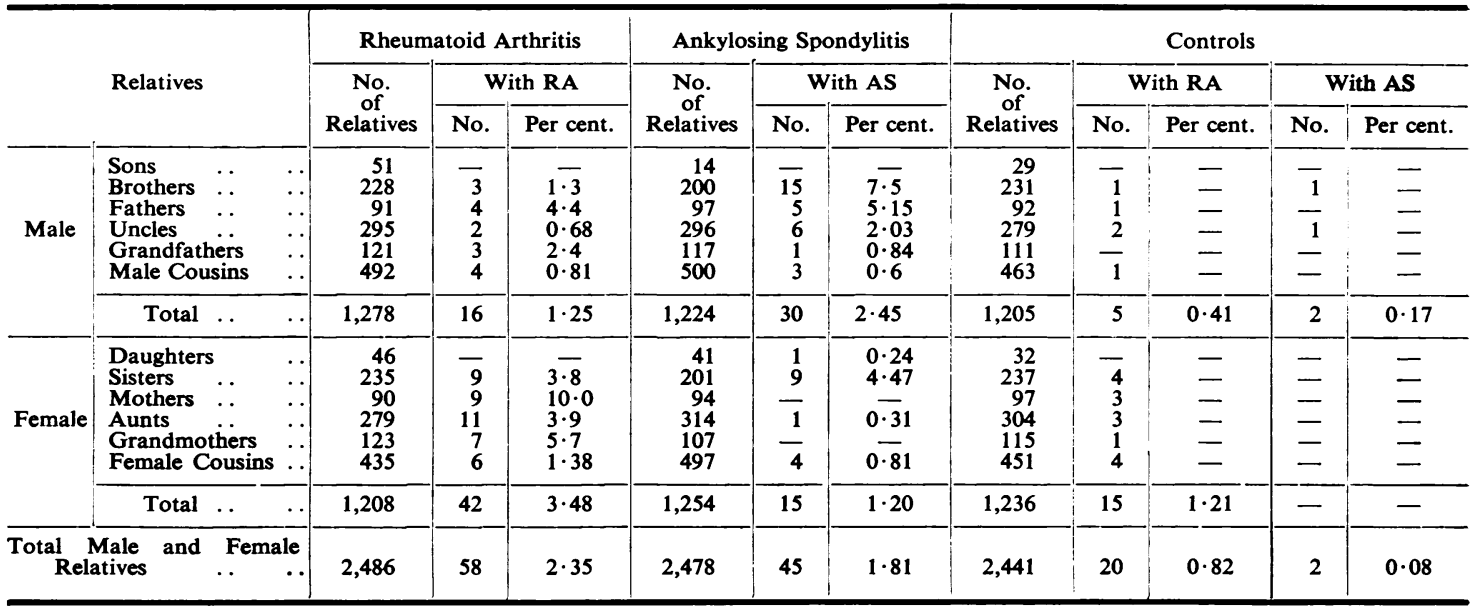

TABLE III

FAMILIES OF PROBANDS-ACCORDING TO THE NUMBER OF SECONDARY CASES

\begin{tabular}{|c|c|c|c|c|}
\hline \multirow{2}{*}{$\begin{array}{l}\text { No. of } \\
\text { Secondary } \\
\text { Cases }\end{array}$} & \multirow{2}{*}{ RA Probands } & \multirow{2}{*}{ AS Probands } & \multicolumn{2}{|c|}{ Control Probands } \\
\hline & & & with RA in Family & with AS in Family \\
\hline 0 & 66 & 70 & 81 & 98 \\
\hline $\begin{array}{l}1 \\
2 \\
3 \\
4 \\
5\end{array}$ & $\left.\begin{array}{r}20 \\
7 \\
5 \\
1 \\
1\end{array}\right\} 34$ & $\left.\begin{array}{r}20 \\
6 \\
3 \\
1 \\
-\end{array}\right\} 30$ & $\left.\begin{array}{c}18 \\
- \\
-\end{array}\right\} 19$ & $\left.\begin{array}{l}2 \\
z\end{array}\right\}$ \\
\hline Total .. & 100 & 100 & 100 & 100 \\
\hline
\end{tabular}

via the female line of descent, and six concerned a brother and/or sister.

Ankylosing Spondylitis Group.-There were thirty families with 45 secondary cases, i.e. a familial occurrence of 30 per cent. Of these thirty familial occurrences, ten were via the male and eight via the female line of descent, and twelve concerned a brother and/or sister.

Control Group.-There were nineteen families with twenty "secondary" cases of rheumatoid arthritis: only one family included two cases and these affected an uncle and a female cousin in the same line of descent. There were only two families with secondary cases of ankylosing spondylitis (one in each, and both males).

Families with both Rheumatoid Arthritis and Ankylosing Spondylitis.-The affected relatives in the rheumatoid arthritis group included two cases of ankylosing spondylitis ( 0.08 per cent.); one of these occurred in a family which also had two secondary rheumatoid arthritis cases (in the same line of descent).

The affected relatives in the ankylosing spondylitis group included fifteen cases of rheumatoid arthritis $(0.61$ per cent.): five in males and ten in females; eight of these cases occurred in families with one or more cases of secondary ankylosing spondylitis, including six in the same line of descent.

Other Forms of Rheumatism.-Although an investigation into the occurrence of other forms of articular rheumatism such as osteo-arthritis and rheumatic fever was not included in our terms of reference, an attempt was nevertheless made to gain some general impression in this respect. Only in very marked cases were these diagnoses registered. Not too much value should therefore be attached to this part of the investigation, which yielded the following results: 
Rheumatoid Arthritis Group.-This included sixteen cases of rheumatic fever ( 0.62 per cent.) and 58 cases of osteo-arthritis $(2 \cdot 35$ per cent.).

Ankylosing Spondylitis Group.-This included sixteen cases of rheumatic fever ( 0.8 per cent.) and 64 cases of osteo-arthritis ( $2 \cdot 6$ per cent.).

Control Group.-This included eight cases of rheumatic fever ( 0.32 per cent.) and 34 cases of osteo-arthritis ( $1 \cdot 39$ per cent.).

A detailed statistical report on these results is given in the Appendix, from which the following conclusions may be quoted here:

"The data indicate that both rheumatoid arthritis and ankylosing spondylitis are capable of familial occurrence and that, consequently, each probably has a hereditary component; it is also indicated that the hereditary components of the two conditions are different in kind.

It may also be noted that the frequency of rheumatoid arthritis found in the control group agreed with that established in the course of the mass investigation into rheumatoid arthritis made by de Graaff (1961).

It appears that about one-third of the families in the Netherlands are affected by rheumatoid arthritis, and about one in seventeen with ankylosing spondylitis.
Both rheumatoid arthritis and ankylosing spondy litis therefore appear to be characterized by familia? occurrence and a hereditary component, but the same. familial and/or hereditary component is not involved in both these forms of articular rheumatism."

\section{Discussion}

Our results thus give support to the view tha年 rheumatoid arthritis and ankylosing spondylitis are not varieties of the same entity, but in some familial and hereditary studies this difference has not been sufficiently taken into account, so that comparisore with our investigation is difficult. Comparison is also impeded by the fact that some investigatorsi do not specify the relationship between the proband and other relatives examined; nor do they mention the completion rate or the composition of the controt group. Some of the results obtained by various groups of workers between 1950 and 1959 aresummarized in Table IV.

The first striking feature of our results is the predominance of secondary cases among female relatives in the rheumatoid arthritis group (3.48. per cent. as against 1.25 per cent. in males), and predominance of secondary cases among male relatives in the ankylosing spondylitis group (2)

TABLE IV

INCIDENCE OF SECONDARY CASES REPORTED BY OTHER AUTHORS

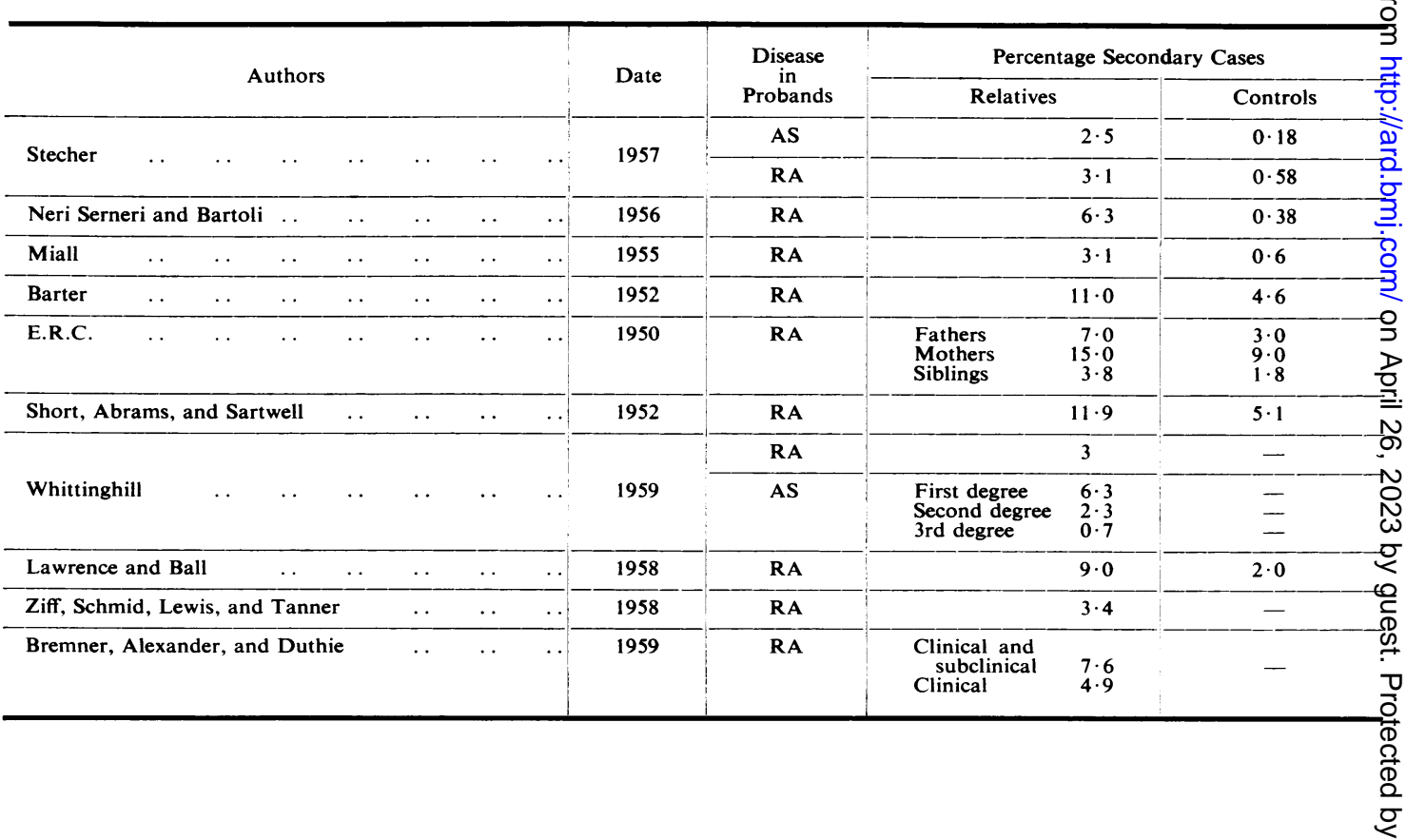


per cent. as against 1.20 per cent. in females). This is entirely in accordance with the general experience that rheumatoid arthritis occurs more frequently in females and ankylosing spondylitis in males.

These secondary cases were seen via both the paternal and maternal lines of descent and gonasomal factors (the X-and Y-chromosomes) are thus unlikely to be of great importance in the hereditary mechanism of these two conditions.

The female and male predominance in rheumatoid arthritis and ankylosing spondylitis respectively might suggest a sex-linked dominance, but we have seen mothers with ankylosing spondylitis who have sons suffering from the same disease, and also fathers with daughters who suffered from rheumatoid arthritis. Stecher (1957) believes that the occurrence of ankylosing spondylitis in a female patient results in an increase in the so-called penetrance (manifestation of an existing hereditary disposition) in the family concerned. Secondary cases were connected with ten of our 24 female probands (41 per cent.) and twenty of our 76 male probands (26 per cent.), and on the basis of these figures our statistician did not wish to go beyond the opinion that there is possibly a "tendency towards promotion of penetrance" in the family of a female proband with ankylosing spondylitis.

The finding of 0.82 per cent. rheumatoid arthritis and 0.08 per cent. ankylosing spondylitis in our control group of 2,441 subjects is in good agreement with the result of a (limited) mass investigation into the frequency of rheumatic conditions carried out in the Groningen area during 1950-1952. Among 3,378 subjects (all over age 15), 1 per cent. had rheumatoid arthritis and $0 \cdot 1$ per cent. had ankylosing spondylitis.

The results of the mass investigation more recently carried out in the Netherlands (to be published, de Graaff, 1961) also agree with the above data, which suggests that about 1 per cent. of the Dutch population suffer from rheumatoid arthritis (unmistakable, though sometimes asymptomatic), while about $0 \cdot 1$ per cent. suffer from ankylosing spondylitis.

Secondary cases were found in nearly three times as many of the relatives of subjects in the rheumatoid arthritis group as in the control group, and in over 22 times as many of the relatives of the ankylosing spondylitis group as in the control group. This indicates that the hereditary component is more important in ankylosing spondylitis than in rheumatoid arthritis. The higher degree of morbidity in first-degree relatives (especially in the case of ankylosing spondylitis) indicates a dominant hereditary mechanism (see Table II). A recessive hereditary mechanism should, however, be indicated by an increased frequency of consanguineous marriages in the rheumatoid arthritis and in the ankylosing spondylitis group. But consanguineous marriages (determined from civil registration documents up to and including the great-grandparents) were enencountered in only one case in the rheumatoid arthritis group, not at all in the ankylosing spondylitis group, and in one case in the control group.

In the two cases of consanguinity, no influence on the occurrence of rheumatoid arthritis (or ankylosing spondylitis) was demonstrable. The consanguineous family in the control group included no case of "rheumatism"; that in the rheumatoid arthritis group included three cases of rheumatoid arthritis in the maternal line (the father's grandparents were first-degree cousins).

It should be pointed out that none of the probands with rheumatoid arthritis or ankylosing spondylitis had parents who were both suffering from the same disease as the proband. This eliminates the occurrence of homozygotes.

Our investigation suggests that both rheumatoid arthritis and ankylosing spondylitis probably involve a non-sex-linked dominant hereditary mechanism, with differences in penetrance between males and females. This accords with the view held by Stecher (1957).

Several investigators, including Short and others (1952) believed that they had observed an increased number of cases of "rheumatism" (all forms) among the relatives of subjects with rheumatoid arthritis and ankylosing spondylitis. We also noticed a trend in this direction, as there were more cases of osteo-arthritis and rheumatic fever in the relations of patients with rheumatoid arthritis and ankylosing spondylitis than in the control group. The statistician was reluctant to base a conclusion on this observation, however, because the differences were relatively slight, and because our investigation was not especially aimed at these conditions.

Although a serological examination (Rose test) was frequently included in the examination of probands and relatives, the figures are insufficient for an investigation into the possible correlation between a positive Rose test and hereditary factors in rheumatoid arthritis which has been suggested by Ziff and others (1958), Lawrence and Ball (1958), and Bremner and others (1959). We have now started an investigation into the correlation between the so-called rheumatoid arthritis factor and the occurrence of secondary cases. Moesmann (1959) has recently thrown doubt on the existence of a hereditary factor; a study of the occurrence of rheuma- 
toid arthritis in heterozygotic and homozygotic twins does not appear to support the view that heredity is important. Our personal observations, however, lead us to maintain that both rheumatoid arthritis and ankylosing spondylitis are likely to involve a non-sex-linked dominant hereditary mechanism, with differences in penetrance between males and females.

\section{Summary}

7,405 relatives (down to and including thirddegree kin) of 300 probands (100 with rheumatoid arthritis, 100 with ankylosing spondylitis, and 100 normal controls) were examined for rheumatoid arthritis or ankylosing spondylitis.

The frequency of rheumatoid arthritis among relatives of the rheumatoid arthritis group was $2 \cdot 8$ times as high as that in the control group; the frequency of ankylosing spondylitis among relatives of the spondylitis group was $22 \cdot 6$ times as high as that in the control group. Ankylosing spondylitis was as frequent in the rheumatoid arthritis group as in the control group. The same holds true for rheumatoid arthritis relative to ankylosing spondylitis. Both rheumatoid arthritis and ankylosing spondylitis, therefore, probably involve a non-sexlinked dominant hereditary mechanism with differences in penetrance between males and females.

One-third of all Dutch families are thus believed to be affected by rheumatoid arthritis.

This investigation was carried out with the financial and statistical help of the Health Organization T.N.O., The Hague.

\section{REFERENCES}

Barter, R. A. (1952). Ann. rheum. Dis., 11, 39.

Blécourt, J. J. de (1951a). Rev. Rhum., 18, 639.

(1951b). Ned. T. Geneesk., 95, 3, 763.

(1954). Ann. rheum. Dis., 13, 338.
Bremner, J. M., Alexander, W. R. M., and Duthie J. J. R. (1959). Ibid., 18, 279.

Empire Rheumatism Council (1950). Ibid., Suppl. vol. 9.

Fox, R. F., and Breemen, J. van (1934). "Chronices Rheumatism." Churchill, London.

Graaff, R. de (1961). Thesis, Leyden. (In the press.) $\vec{\circ}$

Hangarter, W. (1938). "Der Rheumatismus", No. 13. $\overrightarrow{\vec{\omega}}$ Steinkopff, Dresden.

Holsti, Ö., and Huuskonen, A. J. (1938). Acta med.⿳亠丷厂犬 scand., Suppl. 89, p. 128.

Lawrence, J. S., and Ball, J. (1958). Ann. rheum. Dis. స્. $17,160$.

McKusick, V. (1959). Amer. J. Med., 26, 283.

Miall, W. E. (1955). Ann. rheum. Dis., 14, 150.

Moesmann, G. (1959). Acta rheum. scand., 5, 291.

Ropes, M. W., Bennett, G. A., Cobb, S., Jacox, R., and Jessar, R. A. (1957). Ann. rheum. Dis., 16, 118.cs

Neri Serneri, G. G., and Bartoli, V. (1956). Act $\$$ Genet. med. (Roma), 5, 402.

Short, C. L., Abrams, N. R., and Sartwell, P. E. (1952). "Rheumatic Diseases: based on the Proceedingso of the VII International Congress on Rheumatici Diseases", p. 47. Saunders, Philadelphia. 응

Stecher, R. M. (1957). "Heredity in Joint Diseases"Doc. rheum. Geigy, No. 12. Basel.

Whittinghill, M. (1959). "Proceedings of the 1)th International Congress on Genetics, Montreal 1958", vol. 2, p. 314.

Ziff, M., Schmid, F. R., Lewis, A. J., and Tanner, M足 (1958). Arthr. and Rheum., 1, 392.

\section{STATISTICAL APPENDIX}

BY

\section{T. J. D. ERLEE AND E. F. DRION}

The relatives over 15 years of age included some 10 per cent. on whom insufficient data were obtained. Table A (opposite) summarizes the unexamined subjects aged 15 and over and those under 15 years of age. In each group, the number of boys under 15 exceeded the number of girls under 15 , although the difference is not significant. In the older age groups, too, there were more males than females in each group (difference not significant).

Since it is known that both rheumatoid arthritis and ankylosing spondylitis can become clinically manifest at a fairly advanced age, a complete statistical analysis should take into account the age of all subjects included in the investigation. Since the object of this investiga $D$ tion was more limited (to determine whether there are unmistakable indications of a familial occurrence of the diseases in question), it seems justifiable to omie any consideration of the age distribution. The relatives of probands with rheumatoid arthritis tended to bo slightly older than those in the other group; this was seen in the average number of sons and daughters and male and female cousins per family. The older the proband, the greater will be the average number of his descendants. However, the average number of male ${ }^{+}$ and female cousins was only slightly larger than the average in the control group (Table B), and since there 
TABLE A

INACCESSIBLE RELATIONS

\begin{tabular}{|c|c|c|c|c|c|c|c|c|c|c|c|}
\hline \multirow{2}{*}{$\frac{\text { Age (yrs) }}{\text { Sex } \ldots}$} & \multirow{2}{*}{$\frac{\cdots}{\cdots}$} & \multirow{2}{*}{$\cdots$} & \multirow{2}{*}{$\cdots$} & \multirow{2}{*}{$\cdots$} & \multirow{2}{*}{$\cdots$} & \multirow{2}{*}{$\frac{\cdots}{\cdots}$} & \multirow{2}{*}{$\frac{\cdots}{\ldots}$} & \multicolumn{2}{|c|}{ Younger than 15 yrs old } & \multicolumn{2}{|c|}{ Remainder } \\
\hline & & & & & & & & Male & Female & Male & Female \\
\hline Group & $\cdots$ & $\begin{array}{l}\text { Rheu } \\
\text { Anky } \\
\text { Cont }\end{array}$ & $\begin{array}{l}\text { toid } \\
\text { ing } \\
\ldots\end{array}$ & $\begin{array}{l}\text { thri } \\
\text { ondy } \\
\text {. }\end{array}$ & & $\begin{array}{l}\ddot{ } \\
\cdots\end{array}$ & $\begin{array}{l}\ldots \\
\ldots \\
\ldots\end{array}$ & $\begin{array}{l}211 \\
162 \\
166\end{array}$ & $\begin{array}{l}203 \\
146 \\
150\end{array}$ & $\begin{array}{l}188 \\
196 \\
203\end{array}$ & $\begin{array}{l}168 \\
188 \\
181\end{array}$ \\
\hline
\end{tabular}

TABLE B

AVERAGE CHILDREN AND COUSINS PER FAMILY

\begin{tabular}{|c|c|c|c|c|c|c|c|}
\hline & roup & & & & & No. of Children & No. of Male and Female Cousins \\
\hline $\begin{array}{l}\text { Rheumatoid Arthritis } \\
\text { Ankylosing Spondylitis } \\
\text { Control .. }\end{array}$ & $\begin{array}{l}\cdots \\
\cdots\end{array}$ & $\begin{array}{l}\cdots \\
\cdots \\
\cdots\end{array}$ & $\begin{array}{l}\cdots \\
\cdots \\
\cdots\end{array}$ & $\begin{array}{l}\cdots \\
\cdots \\
\cdots\end{array}$ & $\begin{array}{l}\cdots \\
\cdots \\
\cdots\end{array}$ & $\begin{array}{l}0 \cdot 97 \\
0 \cdot 58 \\
0 \cdot 61\end{array}$ & $\begin{array}{l}9 \cdot 27 \\
9 \cdot 89 \\
9 \cdot 14\end{array}$ \\
\hline
\end{tabular}

is no indication that the uncles and aunts were older, elaboration without correction for age distribution would seem to be justified.

Each family in the rheumatoid arthritis group* includes at least one case of rheumatoid arthritis (viz. the proband); mutatis mutandis, the same holds true for the ankylosing spondylitis group.* The proband of the control group," however, has neither RA nor AS. It is consequently impossible to make a simple comparison between the total frequency of RA in the RA Group (and of AS in the AS Group) with the frequency of RA and AS, respectively, in the C Group. However, in each group there are subgroups for which this objec-

* For the sake of simplicity, the three groups will be indicated hereafter as RA Group, AS Group, and C Group, and the diseases as RA and AS. tion does not hold. As probands for each of the three groups, subjects between 25 and 45 years of age were chosen; if the proband is male, then he is likely to be in the same age and sex group as his brothers and male cousins; if the proband is female, then she will belong to the same age and sex group as her sisters and female cousins. Both these groups will be henceforth referred to as the A Category. Subjects of another generation (grandparents, parents, uncles and aunts, sons and daughters) will largely fall outside the age group of the proband; these subjects of another generation than that of the proband, and all subjects of the opposite sex, will be referred to as B Category. It is therefore statistically justifiable to make a simple comparison in the B Category between the test and control groups as to the frequency of the diseases under investigation. This comparison is shown in Tables C and D.

TABLE C

FAMILIES WITH RHEUMATOID ARTHRITIS

\begin{tabular}{|c|c|c|c|c|c|c|c|c|c|}
\hline \multirow[t]{2}{*}{ Proband } & & & & \multicolumn{5}{|c|}{$\begin{array}{c}\text { Number of Families Classified } \\
\text { by Number of Cases of RA } \\
\text { in B Category }\end{array}$} & \multirow[t]{2}{*}{$\begin{array}{l}\text { Number of Families with } \\
\text { One Case of AS in the } \\
\text { Family (A + B Category) }\end{array}$} \\
\hline & & & & 0 & 1 & 2 & 3 & 4 & \\
\hline $\begin{array}{l}\text { Rheumatoid Arthritis } \\
\text { Control }\end{array}$ & $\begin{array}{l}\cdots \\
\ldots\end{array}$ & $\cdots$ & $\ldots$ & $\begin{array}{l}74 \\
84\end{array}$ & $\begin{array}{l}16 \\
16\end{array}$ & $\begin{array}{l}6 \\
0\end{array}$ & $\begin{array}{l}3 \\
0\end{array}$ & $\begin{array}{l}1 \\
0\end{array}$ & 2 \\
\hline
\end{tabular}

TABLE D

FAMILIES WITH ANKYLOSING SPONDYLITIS

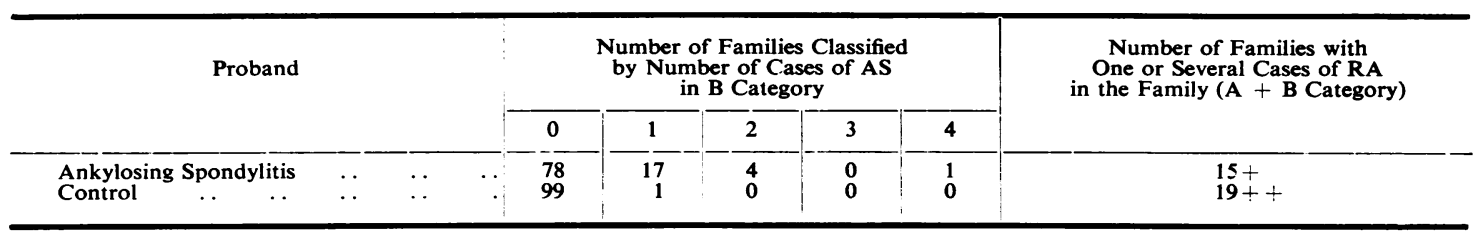

+ All with one patient with RA.

++ Eighteen with one RA patient and one with two RA patients. 
It follows from Table $\mathrm{C}$ that the $\mathrm{B}$ Category of the RA Group has a significantly higher frequency of families with RA than the B Category of the C Group $(P=$ 0.0013 ); a similar conclusion is even more firmly true for the AS Group $(P<0.0001)$. An analysis of this kind can hardly be carried out for the A Category.

Without further calculation it is obvious that the frequencies of AS in the RA and C Groups are as high as the frequencies of RA in the AS and C Groups.

Thus both RA and AS are characterized by familial occurrence, and while families with RA show no increased occurrence of AS, families with AS do show an increased occurrence of RA. Since this conclusion is based on a study of the B Category, most of the members of which (uncles, aunts, grandparents) do not live in the same house as the proband, this familial occurrence must be explained by the existence of a hereditary component for each condition separately.

The series is sufficiently comprehensive to venture an estimate of the chance of clinical manifestation of each disease both among members of the affected families and among members of the $C$ Group. The value of this estimate of the frequencies of the two diseases investigated is that it affords an impression of the order of magnitude of the phenomenon. A "family" as defined here broadly consists of two groups of non-consanguineous subjects, viz. the paternal relatives and the maternal relatives; thus, if one or both diseases is hereditary, the trait will usually prevail in only one of the two branches, and the estimated probability is on the low side.

Former investigations have revealed that clinical symptomatic RA is found in a higher percentage of females than of males, while the reverse is true for $\mathrm{AS}$; the above-mentioned probability therefore, must be calculated for each sex separately. In the RA and the AS Groups, moreover, the probability for male relatives of a male proband and for female relatives of a female proband, must be calculated separately for the A and B Categories. This is because the A Category must always include at least one sick person (i.e. the proband). The manner of calculation and the separate results for the $\mathrm{A}$ and the B Category will be discussed later. The average probabilities are presented in Table $E$.

A comparison of the frequencies of RA in the RA and $C$ Groups can be used as a basis for a rough estimate of the proportion of families in the Netherlands which are affected by RA. For each sex the result obtained is about one in three. A corresponding calculation for
AS can be made only for males, because this disease did not occur in any female in either the $\mathrm{C}$ or the RA $\square$ Group. The result for males suggests that ankylosing? spondylitis occurs in only one out of seventeen Dutch $\Rightarrow$ families.

\section{Calculations}

The probability of occurrence of one of the two conditions equals the average frequency of the disease, 0 making the necessary correction (in the A Category) $\overrightarrow{0}$ for the fact that at least one patient (the proband) has? the disease.

(1) The probabilities in the C Group were calculated by dividing the number of affected subjects of each sex by the total number of subjects of that sex.

(2) The probability of RA in the AS Group and of $\vec{G}$ AS in the RA Group were calculated for each sex $\frac{\text { ? }}{\square}$ separately in the manner indicated under (1).

(3) The probability of RA in the B Category in the RA Group and of AS in the AS Group was calculated for each sex as indicated under (1).

(4) In calculating the probability of RA and $A \stackrel{8}{8}$ respectively, in the $A$ Category, the fact that at least. one patient (the proband) is present in each fam can be allowed for in the following way:

Let $p$ be the probability for the sex under investigation in affected families. Consider all families affected with $k$ subjects in the A Category. The probability that such $\Omega$ a family is included in the investigation is $\left(1-(1-p)^{k}\right), \overrightarrow{\overrightarrow{0}}$ $v i z$. the chance that at least one patient is included in $\exists$ the A Category of this family inducts at least one patient. $\vec{T}$ The mathematical expectation of the number of patients in a family of $k$ subjects is $k p$. Therefore, the conditional mathematical expectation of the number of patients, provided that at least the proband is present (so that $\delta$ the family is included in the investigation), is

$$
\frac{k p}{-(1-p)^{k}} \text {. }
$$

Let the number of patients in the $i$-th family with $k$

TABLE E

AVERAGE PROBABILITIES

\begin{tabular}{|c|c|c|c|c|c|}
\hline \multirow{3}{*}{ Group } & & \multicolumn{4}{|c|}{ A verage Probability of: } \\
\hline & & \multicolumn{2}{|c|}{ Rheumatoid Arthritis } & \multicolumn{2}{|c|}{ Ankylosing Spondylitis } \\
\hline & & Male & Femaie & Male & Female \\
\hline $\begin{array}{l}\text { Rheumatoid Arthritis } \\
\text { Ankylosing Spondylitis } \\
\text { Control }\end{array}$ & $\begin{array}{l}\cdots \\
\cdots \\
\cdots\end{array}$ & $\begin{array}{l}0 \cdot 013 \\
0 \cdot 004 \\
0 \cdot 004\end{array}$ & $\begin{array}{l}0 \cdot 035 \\
0 \cdot 008 \\
0 \cdot 012\end{array}$ & $\begin{array}{l}0.0008 \\
0.024 \\
0.002\end{array}$ & $\begin{array}{c}(0) \\
0 \cdot 012 \\
(0)\end{array}$ \\
\hline
\end{tabular}


subjects be $a_{i k}$, then equating the number found and the expectation gives:

$$
\begin{aligned}
& a_{i k}=z \frac{k p}{1-(1-p)^{k}} \\
&=\frac{k p}{1-\left(1-\frac{k p}{1 !}+\frac{k(k-1) p^{2}}{2 !}-\frac{\left.k(k-1)(k-2) p^{3}+\ldots\right)}{3 !}\right.} \\
&=\frac{k p}{k p-\frac{1}{2} k(k-1) p^{2}+\frac{1}{6} k(k-1)(k-2) p^{3}-\ldots} \\
& \text { or }
\end{aligned}
$$$$
\frac{1}{a_{i k}}=1-\frac{1}{2}(k-1) p+\frac{1}{6}(k-1)(k-2) p^{2}-\ldots
$$

Since the maximal value of $p$ found in this investigation was 0.03 (RA Group females), and since the maximal value of $k$ in women of the RA Group is 23 , so that in this least favourable case the value of the maximal term omitted is only 0.010 , there is no objection to breaking off the series after the term with $p^{2}$.

An estimate of $p$ for the whole series is thus obtained by the equation:

$$
\underset{k}{\epsilon} \underset{i}{\epsilon} \frac{1}{a_{i k}}=\underset{k}{\epsilon} n k\left(1-\frac{1}{2}(k-1) p+\frac{1}{6}(k-1)(k-2) p^{2}\right),
$$

in which $n^{k}$ is the number of families with $k$ subjects in the A Category.

Table $F$ presents the estimates of $p$ obtained by the four methods described above.

TABLE F

ESTIMATES OF PROBABILITY

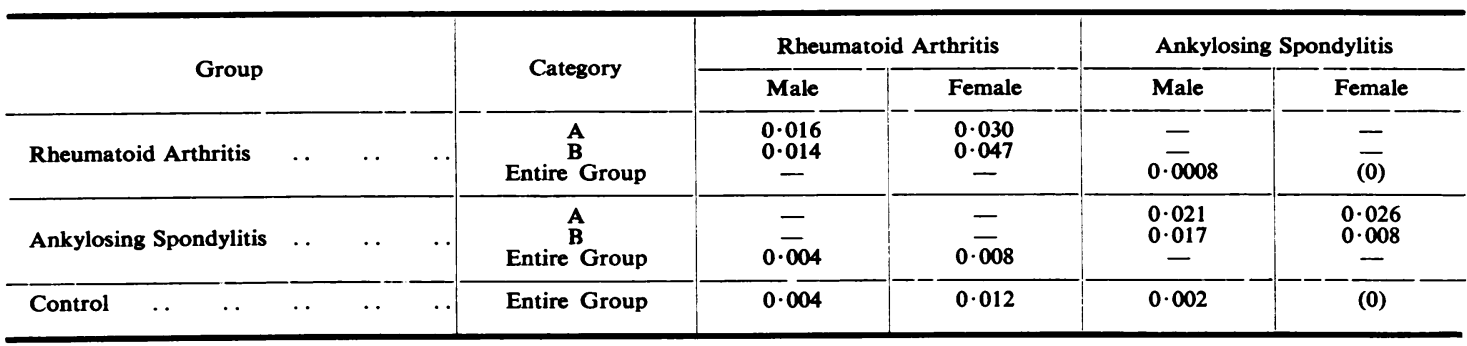

Facteurs héréditaires dans l'arthrite rhumatismale et la spondylarthrite ankylosante

\section{RÉSUMÉ}

7.405 parents (jusqu'à et $y$ compris les parents au troisième degré) de 300 sujets (100 cas d'arthrite rhumatismale, 100 cas de spondylarthrite ankylosante et 100 témoins normaux) furent examinés pour rechercher l'arthrite rhumatismale ou la spondylarthrite ankylosante.

La fréquence de l'arthrite rhumatismale parmi les parents du groupe arthritique rhumatismal fut 2,8 fois plus grande que parmi ceux du groupe témoin; la fréquence de la spondylarthrite ankylosante parmi les parents du groupe spondylarthritique fut 22,6 fois plus grande que parmi ceux du groupe témoin. La spondylarthrite ankylosante fut aussi fréquente dans le groupe témoin. Il en fut de même pour l'arthrite rhumatismale en relation à la spondylarthrite ankylosante. Par conséquent, autant l'arthrite rhumatismale que la spondylarthrite ankylosante impliquent probablement un mécanisme héréditaire dominant, sans linkage sexuel, avec des différences de pénétration entre les hommes et les femmes.

On croit qu'un tiers de toutes les familles hollandaises se trouve affecté par l'arthrite rhumatismale.
Factores hereditarios en artritis reumatoide y espondilartritis anquilosante

\section{SUMARIO}

7.405 parientes (hasta e incluyendo el parentesco del tercer grado) de 300 sujetos (100 con artritis reumatoide, 100 con espondilartritis anquilosante y 100 personas normales) fueron examinados respecto a artritis reumatoide $o$ espondilartritis anquilosante.

La frecuencia de la artritis reumatoide entre los parientes del grupo con artritis reumatoide fué 2,8 mayor que entre los del grupo testigo; la frecuencia de la espondilartritis anquilosante entre los parientes del grupo con espondilartritis dué 22,6 veces mayor que entre los del grupo testigo. La espondilartritis anquilosante fué tan frecuente en el grupo de artritis reumatoide como en el grupo testigo. Lo mismo fué observado respecto a la artritis reumatoide en relación con la espondilartritis anquilosante. Tanto la artritis reumatoide como la espondilartritis anquilosante implican, pués, probablemente un mecanismo hereditario dominante, sin enlace sexual, con diferencias de penetración entre machos y hembras.

Se cree que una tercera parte de todas las familias holandesas está afectada por artritis reumatoide. 